Dr. Marshall Hall's yacht Norna off the west coast of Europe, no animal forms have been discovered, so far as I am aware, identical with chalk fossils. Additional evidence has, however, been procured that over a large part of the bottom of the Atlantic a deposit is being formed mainly of disintegrated globigerinæ and other foraminifera and coccoliths, which appears to be undistinguishable from the ancient chalk.

Not fewer than twenty genera of vitreous sponges have been dredged belonging to two groups, the Hexactinellidæ and the Lithistidæe of Oscar Schmidt, both of which groups are highly characteristic of the chalk and greensand. These sponges are in vast numbers, like the ventriculites and their allies in older Cretaceous beds; and they, with other silicious organisms equally abundant in the modern chalk area, seem to be capable of supplying that amount of silica in a fine state of division which might explain the production of chalk flints. A large series of echinoderms were found, recalling to a remarkable degree, from the profusion of Cidarids and of star-fishes of such genera as Archaster, Astrogonium, and Stellaster, the general facies of the chalk echinoderm fauna; and besides this general resemblence, members of several families have been recovered which were supposed to be extinct. Salenocidaris varispina A. Ag., dredged by De Pourtales in the Strait of Florida, is a living Salenia; Echinolampas caratomoides A. Ag. perpetuates some of the most marked characters of the Galeritidæ. Pourtalesia, a genus first found by Count Pourtales and afterwards in the Porcupine expedition, is a true Dysaster. Porocidaris purpuratus, a fine species dredged off the Butt of the Lews, represents a genus hitherto known only by some isolated plates and radioles. Two very remarkable generic forms, dredged from the Porcupine off the coasts of Scotland and Portugal, only known from some fragnents in the English white chalk, found a new family near the Diademidx. Some new ophiurids approach their fossil ancestors; and off the coast of Portugal the dredge brought up at one rich haul twenty or thirty examples of a fine Pentacrinus ; while over the whole area Rhizocrinus loffotensis, a degenerate little Bourgueticrinus, seemingly one of the last of the pear-encrinites, is abundant.

I am not in a position to say much about those groups which I have not personally examined, except that Mr. Gwyn Jeffreys and Prof. Martin Duncau report that among the mollusca and corals many species occur which have been hitherto known only as fossils, principally, as might have been expected, in comparatively shallow water forms in the Tertiaries.

$I$ do not see that there is any object in attempting to explain this singular resemblance between these deep-sea deposits in the Atlantic and the old chalk in composition and structure and in embedded fauna on any other assumption than that of a continuity of conditions over some part at all events of the area. During the lapse of time, while the fauna of shallower water has again and again undergone almost total change by changes in the distribution of temperature and in the distribution of sea and land, the fauna of the deep water has been also affected. To a depth of 5,000 feet it is at present heated over a large portion of the North Atlantic many degrees above its normal temperature. Accepting, as I believe we are now bound to do, some form of the doctrine of the gradual alteration of species through natural causes, one is quile prepared to expect a total absence of the identical forms found in the old chalk. The utmost which might be anticipated is such a resemblance between the two faunze as might justify the opinion that the later fauna bears to the earlier the relation of descent with extreme modification. Sir Charles Lyell asks if we have dredged belemnites, ammonites, baculites, hamites, turrilites, \&c. ; that question is, I think, best answered by the record of the old Cretaceous beds themselves, which are scarcely more remarkable for the presence of these singular and beautiful forms than for their rapid extinction. According to the view which $I$ have felt myself compelled to adopt, the various groups of fossils characterising the Tertiary beds of Europe and North America represent the constantly altering fauna of the shallower portions of an ocean whose depths are still occupied by a deposit which has been accumulating continuously from the period of the pre-Tertiary chalk, and which perpetuates with much modification the pre-Tertiary chalk fauna. I do not see how this view militates in the least against the "reasoning and classification" of that geology which we have learned from Sir Charles Lyell. Our dredgings only show that these abysses of the ocean which Sir Charles Lyell admits in the passage quoted above to have outlasted on account of their depth a succession of geological epochs, are inhabited by a special deep-sea fauna possibly as persistent in its general features as are the abysses themselves. WyVILLE THOMSON

\section{Ocean Currents}

AtTEnTION has been much drawn of late to the subject of Ocean Currents and their causes, and it has occurred to me that there is a directing if not an originating cause of these streams, which has, so far as I am aware, been overlooked by physicists. It is known* that at some parts of the earth's surface there exists an atmospheric pressure capable of sustaining a column of mercury in the barometer of upwards of 30 inches in height; at the same time there are certain areas over which this pressure is only such as to raise the barometric column to a little over 29 inches. Now if we compare the difference of absolute weight sustained by two such areas, we shall see that in the space over which the higher atmospheric pressure exists, there is an excess of weight of air, amounting in round numbers to $I, 000,000$ of tons on each square mile. Applying this fact to the region of the ocean in which the surface currents are best known, the North Atlantic, we find from the isobaric chart that there is throughout the year over a large portion of the eastern side of this sea, next the const of North Africa, a pressure (to use the convenient mode of expressing it) of upwards of $30 \% 2$ inches. To westward of this space, towards the Gulf of Mexico and the coast of the United States, the average pressure decreases; between Newfoundland and the British Isles the pressure is still diminished, till in the wide channel between Iceland, Norway, and Spitzbergen, we arrive at a yearly pressure of less than $29^{\circ} 6$ inches. It is reasonable to believe that the waters which lie linder the high pressure area have a tendency to escape from under the excessive weight, towards the space over which the pressure is less. But the high pressure area next the African coast is precisely that upon which the north-east trade winds descend, and the waters, aided in their choice of an exit, will naturally flow off to south-westward before the wind. Their continuance in this direction is barred, however; for across the whole of the southward passage between Africa and South America, there exists another belt of high pressure, out of which the south-easierly trade winds blow. The only course left for the escaping waters (allowing for the moment that the excess of pressure is a cause of their movement) is to westward, where the pressure is lessened, towards the Gulf of Mexico, and the east coast of America, and thence towards the low pressure space between Iceland and Norway. But this is exactly the course that the Gulf Stream, or rather the North Atlantic warn stream of which the Gulf Stream is the most prominent feature, is seen to take. Are we not then warranted in concluding that the difference of atmospheric pressure has some power both in originating and in directing the course of this ocean current?

In suggesting the unequal distribution of atmospheric pressure as a supplementary cause to difference of temperature and of density, to evaporation, rain, and winds, and to whatever further agents there may be in the production of ocean currents, I would venture to express a hope that some one in authority, by carefully comparing and valuing the power of each one of these motive forces, and their application to the known streams, will give to the world a system of the causes of ocean currents which will be vastly more relevant to the phenomena these streams are known to present, than any one of the theories which have as yet been put forth.

When we know that Sir John Herschel gives to the winds the entire right of setting the ocean streams in motion; that Captain Maury holds the universal circulation of the sea to be caused by nothing else than the differences in its specific gravity, and that Dr. Carpenter (or rather Professor Buff) would bring about a general interchange of polar and equatorial water by the aid of sunshine and frost alone; is it not time to ask which of these three causes we should accept as the true one, or if all three are partially concerned, what part is to be taken from each to let the others have their fair share in the work?

Keith Johnston, Jun.

The Measurement of Mass

I AM happy to meet with an opponent who comes so directly to the point as my Reviewer, W. M. W.

* I wonld refer those who desire to look more particularly into this matter to the monthly isobaric charts prepared by Mr. Buchan, to illustrate hi admirable paper on the mean pressure of the atmosphere. Trans. Roya Soc. Edin., vol. $x \times y$, 